\title{
AUTUMNBOOKS
}

\section{Relics of the modern mind}

\section{Our enduring search for meaning in life explains the reverence with which the bones of seventeenth-century French philosopher René Descartes were worshipped, suggests Lisa Jardine.}

\author{
Descartes' Bones: A Skeletal History of the \\ Conflict Between Faith and Reason \\ by Russell Shorto \\ Doubleday: 2008. 320pp. \$26
}

In spring 1666, the body of the French philosopher and scientist René Descartes was removed from its resting place in the undistinguished Adolf Fredriks churchyard in the northeast of Stockholm where it had been buried quietly 16 years earlier, and transported under cover of darkness to the residence of the French ambassador to Sweden, Hugues de Terlon. There, under de Terlon's reverential supervision, the coffin was opened. Its contents were transferred to a small, specially made copper coffin to be transported to a more appropriate resting place in Paris. Thus began the curious peregrinations of Descartes' bones.

By the time de Terlon's convoy set off for home, Russell Shorto tells us in his beguiling new book, Descartes' Bones, fragments of the controversial thinker's earthly remains had already started to be dispersed, as admirers licitly and covertly acquired relics - souvenirs to be treasured and revered, and handed down through the generations.

Shorto confesses that when he began to investigate the story of Descartes' remains passing down through the centuries, he "fell in love with it, the way you can only fall in love with something truly odd that you find buried in a very old book". As he pursued the fortunes of the bones - and above all the separated skull - through the historical records, he realized that there was more to the story than mere curiosity. Here was "a historical detective story about the creation of the modern mind".

In their attitudes to the relics, Shorto argues, successive generations of Descartes' admirers and detractors betrayed their own deeply held beliefs about the limits of rationality, and the

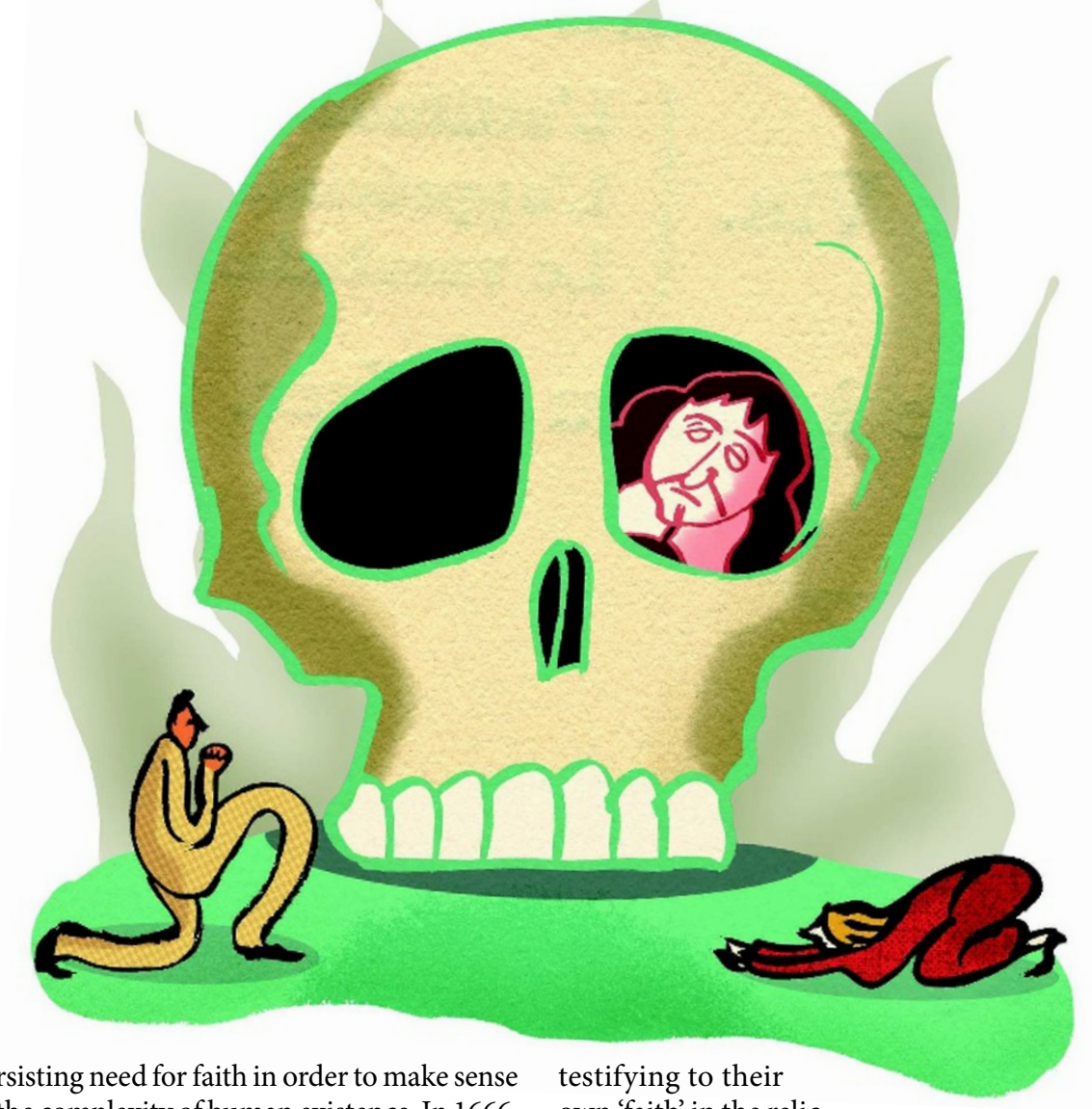

of the complexity of human existence. In 1666, de Terlon had requested the authorities that he might himself be allowed, "religiously", to take possession of Descartes' right index finger, the bone "which had served as an instrument in the immortal writings of the deceased". The Swedish family that became the proud owners of Descartes' skull - how, it is not clear - had it lovingly inscribed with Latin verses celebrating its significance as a souvenir of the beginnings of rationality. Successive owners added their own signatures and inscriptions own 'faith' in the relic.

According to the traditional history of philosophy, Descartes' statement "Cogito, ergo sum" and his committed view that the human body is a well-ordered machine, threatened to drive faith and human emotions out of the discourse of humanity. The story of Descartes' bones is, according to Shorto, the tale of each generation's struggle to retain its most deeply held spiritual beliefs in the face of such mechanistic explanations, an emotional attempt to bridge the mind-body dualism.

\section{NEW IN PAPERBACK}

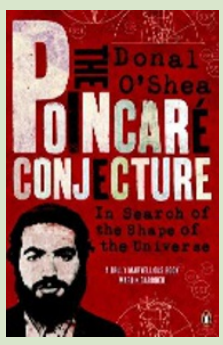
of the Universe
The Poincaré Conjecture: In Search of the Shape

by Donal O'Shea (Penguin, $€ 9.99$ )

One of the great mathematical theories, the Poincare conjecture defied proof for a century until it was solved in 2006 by an eccentric Russian mathematician. In his enthralling book, O'Shea explains the mathematics behind the conjecture, its proof and the curious personalities involved.

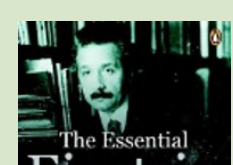

Einstein His Greatest Works Stephen Hawking
The Essential Einstein: His Greatest Works Edited, with commentary, by Stephen Hawking (Penguin, E12.99)

Collecting the highlights of his work, this book presents Einstein's view of physics and the world in his own words. Hawking introduces each section, summarizing the historical context and impacts of Einstein's discoveries. 
Each step in the detective investigation contributes to our understanding of these same issues today. At the height of the French Revolution, for instance, Alexandre Lenoir became the self-appointed custodian of the human remains and historic relics preserved across France in churches and chapels, volunteering to rescue them from the desecration of the marauding mobs and place them in his own 'hall of antiquities' for safe keeping. He went about his task with revolutionary - or perhaps, Shorto suggests, religious - zeal, assembling huge quantities of stonework and statuary, and logging its acquisition with care.

As reason replaced faith in the new French Republic, Lenoir rescued the bones of France's greatest rationalist from the church of St Geneviève in Paris where they had lain since de Terlon recovered them from Sweden. Meanwhile, on the eve of the Terror, a French revolutionary committee decreed that the bones should be moved to the Pantheon - the new secular cathedral of the revolution - and a statue erected to Descartes' memory. Not for the first time, however, events overtook the best of intentions. In spite of an official decree of the ruling National Convention, the bones stayed in Lenoir's macabre museum, where he laid out his tombs and funerary statuary in a pleasure garden in which visitors could wander at will and "ponder beauty and death".

Once again, the whereabouts of Descartes' bones become shrouded in mystery. It is not even clear that Lenoir's rescued remains were those of the father of rationalism. Nor is it clear what happened to them thereafter. They seem to have gone missing among the carefully documented treasures in Lenoir's museum.

For Shorto, his own fascination with this curious piece of narrative history is a mirror for the concerns of each and every one of us, bewildered by modernity and struggling to find meaning and belief in a confusing world. His piecing together of the fortunes of Descartes' bones is elegantly interwoven with the intellectual history of Cartesian philosophy and beliefs, as well as with the history of the uncomfortable relationship between Catholicism and Cartesianism. His suggestion is, I think, that we cannot escape from our felt need for faith and devotion, and that, deprived of religious relics we turn to secular forms of worship.

I am not sure that our attitude to mortal remains has not always sat apart from the rest of our thinking and feeling - a place of talisman and taboo that brings out in us, from the depths of our soul as it were, our most primitive, elemental feelings and attitudes, however rational our outlook.

Between 1640 and 1660, for example, an English gentleman named John Bargrave embarked on a 'grand tour' of Europe in search of unusual items to assemble in a fashionable cabinet of curiosities. When he returned to England he became a canon of Canterbury Cathedral, to which he bequeathed his carefully catalogued collection. The Bargrave cabinets can still be seen there today. It is, in a way, a biography in a box, testifying in its varied items to Bargrave's personal passions and interests. There is a beautifully constructed model of an eye, which can be dismantled to show its inner structure. There are 34 saints' bones bought for 2 shillings and 6 pence (about $\mathfrak{£ 2 0 0}$ or US $\$ 350$ today). There are tiny antique statues, rings, trinkets, each lodged in its own drawer and accompanied by a description of what it is and where it was found.

Just as in the case of Descartes' bones, Bargrave's cabinets reveal an intense fascination on Bargrave's part for relics and human remains. One of the items in it - which I have myself, somewhat tremulously, handled - is 'the finger of a Frenchman'. Bargrave's catalogue tells us of the "danse macabre" put on for him at the monastery at Toulouse where he acquired it and where "all the dead men and women's corpses that are buried there are dried into a kind of mummy". He wrote: "They showed us the corpse of a physician (of their acquaintance), which, when they put a clean piece of paper into one hand and a pen into the other, stood in such a posture as if he had seriously been a-writing a dose or prescription."

Bargrave's macabre trophy is a reminder of our enduring fascination with remnants and reminders of our own mortality. Shorto's beautifully written book does likewise - the reader will find its intellectual insights entertaining, enlightening and, perhaps, disturbing. Lisa Jardine is director of the Centre for Editing Lives and Letters and centenary professor of Renaissance Studies at Queen Mary, University of London, London E1 4NS, UK. Her latest book is Going Dutch: How England Plundered Holland's Glory.

\section{Psychology's pet subject}

\section{Alex \& Me: How a Scientist and a Parrot Discovered a Hidden World of Animal Intelligence - and Formed a Deep Bond in the Process \\ by Irene Pepperberg \\ HarperCollins: 2008.240 pp. $\$ 23.95$}

Alex and $\mathrm{Me}$ is the conjoined life story of cognitive psychologist Irene Pepperberg and her African grey parrot, Alex. Pepperberg sketches her life from lonely girlhood in Brooklyn, New York, through college and graduate school - she attended the Massachusetts Institute of Technology aged 16, and gained $\mathrm{PhD}$ in theoretical chemistry at Harvard University - to her acquisition of Alex in 1977. Pepperberg helped Alex to develop the use of spoken words to identify numbers, colours, materials, shapes and categories of objects. She struggled to gain respect and recognition from the academic community for her work, and this takes centre stage in her account.

The book starts and ends with Alex's death in September 2007. The public response to his demise underscored his celebrity status. Outpourings of grief reached Pepperberg from all around the world - even The Economist ran an obituary. She conveys effectively her shock at losing not just her main research subject, but

\section{New Theories of Everything} by John D. Barrow (Oxford Univ. Press, £8.99) Updating his 1991 work, Theories of Everything, Barrow looks at the latest discoveries and theories about the Universe and explores their philosophical and cultural implications. He shows how the search for a Theory of Everything leaves us more aware of the richness and complexity of the cosmos.

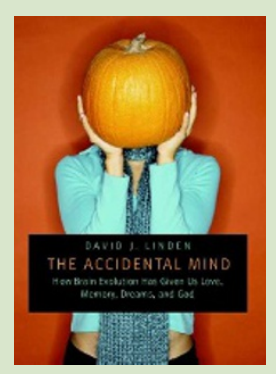

The Accidental Mind: How Brain Evolution Has Given Us Love, Memory, Dreams, and God by David J. Linden (Harvard Univ. Press, \$17.95) Linden's introduction to brain science is enjoyable and accessible. "Even readers trained in neuroscience are likely to enjoy the many tidbits of rarely taught information - on love, sex, gender, sleep and dreams - that spice up Linden's main argument," wrote reviewer Georg Striedter (Nature 447, 640; 2007). 